\title{
Role of endomycorrhizae, rhizobacteria and compost to improve phosphorus availability in onion
}

\author{
Faiza Shahzad ${ }^{1}$, Hafiz Naeem Asghar ${ }^{1}$, Zain Mushtaq ${ }^{1}$, Amina Hadayat ${ }^{1}$, Naqshe Zuhra ${ }^{1}$, Rizwan Ahmad ${ }^{2}$, \\ Muhammad Arif Ali ${ }^{3}$ \\ ${ }^{1}$ Institute of Soil and Environmental Sciences, University of Agriculture, Faisalabad, Pakistan \\ ${ }^{2}$ Land Resources Research Institute, National Agricultural Research Centre, Islamabad, Pakistan \\ ${ }^{3}$ Department of Soil Sciences, Bahauddin Zakariya University, Multan, Pakistan
}

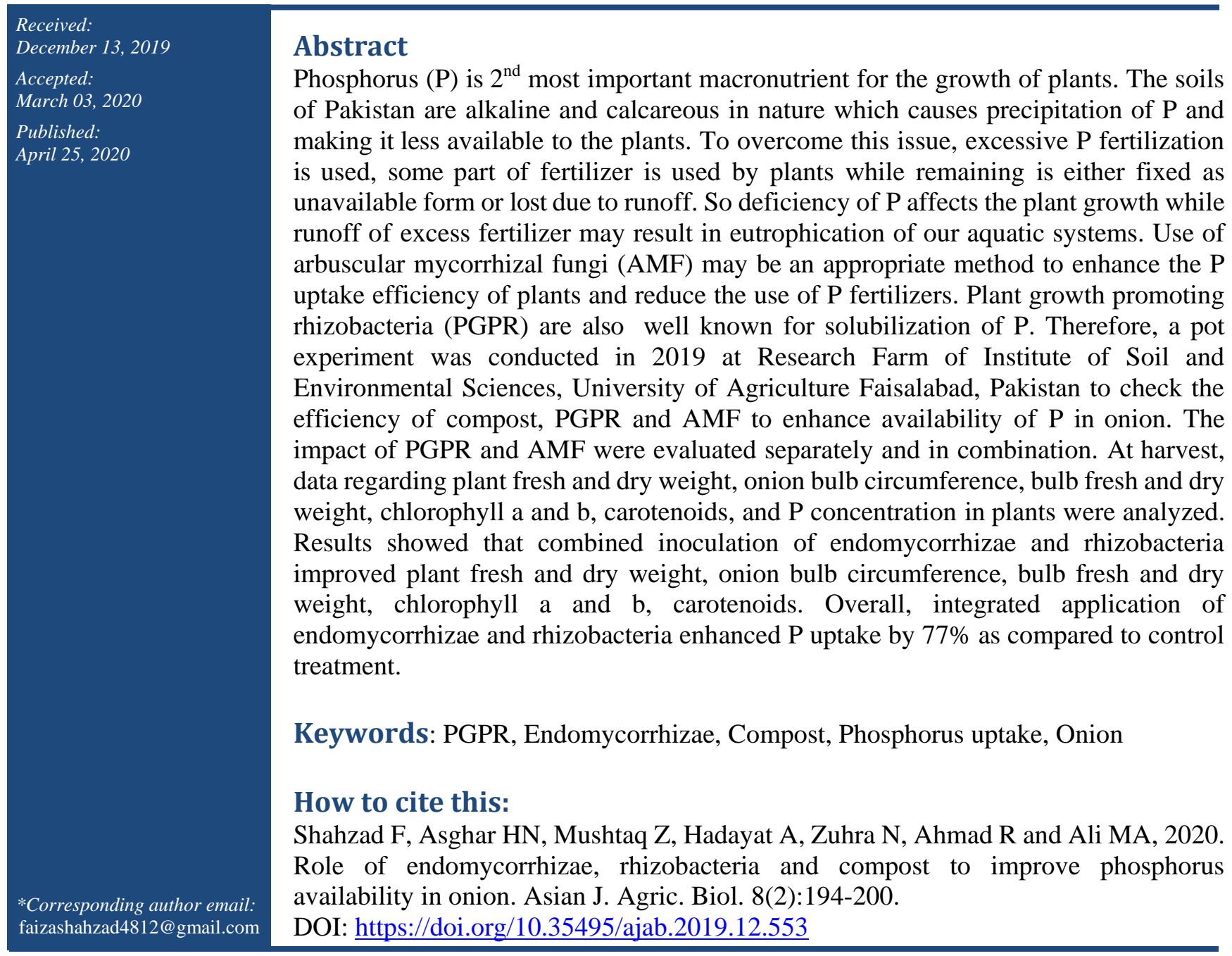

This is an Open Access article distributed under the terms of the Creative Commons Attribution 3.0 License. (https://creativecommons.org/licenses/by/3.0), which permits unrestricted use, distribution, and reproduction in any medium, provided the original work is properly cited.

\section{Introduction}

Phosphorus is the second most important nutrient for plant growth after nitrogen (Raghothama, 1999). Phosphorus plays an important role in plant metabolism and development. It is an important part 
of multiple processes like synthesis of nucleic acid, fixation of nitrogen, glycolysis, formation and stability of membrane, redox reactions, carbon metabolism, cell signaling, energy transfer and generation and enzyme activation or inactivation (Rengel and Zhang, 2011).

Balanced uptake of $\mathrm{P}$ enhances many developmental processes like fruiting, flowering, root growth and shoot growth (Williamson et al., 2001). It is a necessary part of nucleic acids, phospholipids, nicotinamide adenine dinucleotide phosphate (NADPH), adenosine triphosphate (ATP) and sugar phosphates which are very important compounds of the process of photosynthesis (Hammond and White, 2008). Even, very minute deficiency in $P$ has very large impacts on development and growth of plants (Carstensen et al., 2018).

Pakistan soils have $\mathrm{pH}$ greater than 7.0 and have more than $3 \% \mathrm{CaCO} 3$ (Niaz et al., 2007). The most suitable $\mathrm{pH}$ for all vegetables is between 5.5 to 7.0. Onion is one of the important vegetable used throughout the year in every house. Onion bulbs and green leaves are used in preparation of vegetables or eaten raw. They are used in sauces, soups or for seasoning foods. Onions play a role in preventing heat stroke and several other ailments. Onion bulbs are rich in carbohydrates, phosphorus and calcium. Onion are grown in several cities of Pakistan, like Vehari, Hyderabad, Kasur, Sanghar, Nawabshah, Mirpurkhas, Badin, Dadu, Ghotki, Kalat, Chaghi, Turbat, Swat, Jaffarabad etc. (Khokhar, 2018). Moving from less to extreme P deficiency, 90\% of Pakistani soil suffers from $P$ deficiency (Alam et al., 1994). Inorganic P is the only bioavailable form for uptake by plants but it is less available due to chemical fixation and making complexes with different elements at low as well as high pH (Shen et al., 2011). Due to chemical fixation of $\mathrm{P}$, excessive $\mathrm{P}$ fertilization is done to fulfill plant requirements but only $20 \%$ of applied $\mathrm{P}$ is utilized by plants (Cordell and White, 2015). These fixation reactions reduce the solubility of $\mathrm{P}$ by converting it into compounds which are less soluble and ultimately reduce the $\mathrm{P}$ availability to plants (Leytem and Mikkelsen, 2005). Less availability of $P$ fertilizer can reduce crop yield and overuse of $\mathrm{P}$ fertilization can cause eutrophication of aquatic systems (Baker et al., 2015).

There are several different methods to enhance the availability of P like organic amendments, agronomic practices, $\mathrm{P}$ efficient cultivars, phosphate solubilizing bacteria, arbuscular mycorrhizal fungi, composting etc. (Kunwar et al., 2018). One of the most appropriate solutions is the use of mycorrhizal fungi because it helps in the uptake of $\mathrm{P}$ by plants and produce high yield under limited supply of P (Marschner, 1995). Mycorrhizae is a symbiotic relationship in which soil derived nutrients are supplied by external mycelium of a fungus to the roots of plants (Balestrini et al., 2015). The AMF enhance the availability and uptake of $\mathrm{P}$ by plants through different mechanisms. Like network of hyphae helps to extend the root system of plants and explore more soil volume in order to get access to the available P (Elbon and Whalen, 2015). Arbuscular mycorrhizal fungi (AMF) changes the $\mathrm{pH}$ of soil in root zone and release organic acids (Tawaraya et al., 2006) which leads to the solubilization of $\mathrm{P}$ minerals and release phosphate ions (Kirk, 1999). The AMF releases phosphatase which is an enzyme used for mineralization of organic phosphate into phosphate ions which diffused faster into the hyphae (Koide and Kabir, 2000).

Plant growth promoting rhizobacteria (PGPR) are located in root area, and thus increase plant growth (Ahemad and Kibret, 2014). The PGPR have some direct and indirect mechanisms. These mechanisms include the synthesis and excretion of enzymes, organic acids, biologically active substances and hormones. Such P solubilizing bacteria enhance plant growth, yield and uptake of nutrients (Glick, 2005). Microbially mediated biologically active substances and hormones increase $\mathrm{P}$ uptake by stimulating growth of plant roots (Sharma et al., 2013).

In relationship of fungus and bacteria, bacteria improves the AMF activity, while in return, fungus supports bacteria to mobilize $\mathrm{P}$ from immobile sources and to fix nitrogen (Nadeem et al., 2017). Mycorrhizae inoculation with different strains of bacteria shows positive impact on the growth of plants. Bacteria also enhance the penetration of fungus into the roots (Jeffries et al., 2003). A study was executed by Tanwar et al. (2012) to find the combined interaction of Pseudomonas fluorescens and endomycorrhizae fungi on bell paper (Capsicum annuum L.) under different levels of $\mathrm{P}$. They concluded that their combined effect enhanced the root colonization of arbuscular mycorrhizae, $\mathrm{P}$ uptake, and activity of phosphatase with the lowest level of $\mathrm{P}$ fertilizer which ultimately enhanced the yield of Capsicum annuum $\mathrm{L}$.

Compost increases $\mathrm{P}$ availability directly because it is an important source of $\mathrm{P}$ for the growth of plants (Prasad, 2013) a s we 11 a s indirectly by effecting 
microbial activities, producing organic acids, blocking fixing sites for $\mathrm{P}$. This increased $\mathrm{P}$ mineralization and ultimately $\mathrm{P}$ uptake by plants enhance growth of plants (Khan and Joergensen, 2009). Addition of compost enhances soil organic material and activity of microbes. These microbes decompose organic matter and feed on them. Due to decomposition process, organic acids are released and these organic acids help to make symbiotic relationship with AMF (Kumar et al., 2012).

Keeping in view the importance of PGPR, AMF and compost, present experiment was performed to find out the impact of AMF and PGPR along with compost on $\mathrm{P}$ uptake and growth of onion in order to reduce our dependence on chemical fertilizers and protect our environment.

\section{Material and Methods}

An experiment was conducted to evaluate the combined effect of AMF, rhizobacteria and compost to enhance the efficiency of $\mathrm{P}$ to improve growth and yield of onion. Furthermore, to suppress the wastage of $\mathrm{P}$ by efficient utilization of added $\mathrm{P}$ in the wire house under ambient conditions. Strain of $G$. intraradices and rhizobacteria and compost were used alone or in combination. Each treatment was repeated thrice. In each pot, $10 \mathrm{~kg}$ of soil was filled. Onion nursery was taken from private farm. For inoculation of Glomus Intraradices (AMF), same quantity of inoculum was added in the respective pots and then nursery was placed over it. For inoculation with bacteria, first of all $250 \mathrm{~mL}$ of Lauria Bertani (LB) broth was prepared, bacterial strain was mixed and left in orbital shaker for 3 days at $28^{\circ} \mathrm{C}$ temperature. Then onion bulbs were dipped in the inoculum for 1 hour and transplanted to the respective pots. Compost was used as a source of organic matter at a rate of $2 \%$ in respective treatment as per plan. Recommended dose of $\mathrm{N}: \mathrm{P}: \mathrm{K}$ for onion at the rate of $50: 35: 25 \mathrm{~kg} \mathrm{ha}^{-1}$, respectively, was applied to each pot except one treatment containing $G$. intraradices, rhizobacteria and compost in combination. Good quality water was used for irrigation. Crop was harvested after 3 months. The growth parameters like bulb weight, bulb size, fresh weight and oven dry weight were recorded. Chlorophyll a and b, carotenoids (Arnon,
1949) and SPAD value (SPAD-502 m) was determined.

Soil and plant were analyzed for $\mathrm{P}$ concentration by Olsen method (Olsen, 1954) and Yellow color method (Jackson, 1958), respectively. Data was statistically analyzed by complete randomized design (CRD) under factorial arrangements using computer-based statistical software Statistix-8.1 (Analytical Software, Tallahassee, USA). Treatment means were compared using Honestly Significant Difference (HSD) (Montgomery, 2013).

\section{Results}

\section{Growth parameters}

Glomus intraradices (endomycorrhizae) and plant growth promoting rhizobacteria along with compost were effective in increasing the growth parameters. The combined inoculation of G. intraradices and PGPR enhanced the plant fresh weight by $61 \%$ and $74 \%$, plant dry weight by $65 \%$ and $82 \%$, bulb fresh weight by $34.18 \%$ and $42.98 \%$, bulb dry weight by $60 \%$ and $66 \%$ as compared to sole application of G. intraradices or rhizobacteria, respectively. Similarly, bulb circumference was increased by $19 \%$ and $22 \%$ when AMF and PGPR were used together as compared to their alone application. However, an increase of $26 \%$ plant fresh weight, $15 \%$ plant dry weight, $20 \%$ bulb fresh weight, $28 \%$ bulb dry weight and $8 \%$ bulb circumference were observed when AMF and PGPR were applied together as compared to the plants which were treated with AMF and compost. Similarly, dual inoculation of endomycorrhizae and rhizobacteria increase the plant fresh weight by $32 \%$, plant dry weight by $18 \%$, bulb circumference by $11 \%$, bulb fresh weight by $23 \%$ and bulb dry weight by $34 \%$ in contrast to application of rhizobacteria along with compost.

Table-1: Properties of pre-analyzed soil (used in pot experiment)

\begin{tabular}{|l|c|c|}
\hline \multicolumn{1}{|c|}{ Characteristics } & Unit & Value \\
\hline $\mathrm{pH}_{\mathrm{s}}$ & & 7.7 \\
\hline $\mathrm{EC}_{\mathrm{e}}$ & $\mathrm{dS} / \mathrm{m}$ & 1.41 \\
\hline Saturation percentage & $\%$ & 37.8 \\
\hline Available phosphorus & $\mathrm{mg} / \mathrm{kg}$ & 6.58 \\
\hline
\end{tabular}


Faiza Shahzad et al.

Table-2: Impact of endomycorrhizae and PGPR along with compost on growth parameters of onion.

\begin{tabular}{|c|c|c|c|c|c|}
\hline Treatments & $\begin{array}{c}\text { Plant fresh weight } \\
\left(\text { g pot }^{-1}\right)\end{array}$ & $\begin{array}{c}\text { Plant dry weight } \\
\left(\mathrm{g} \mathrm{pot}^{-1}\right)\end{array}$ & $\begin{array}{c}\text { Bulb fresh weight } \\
\left(\text { g pot }^{-1}\right)\end{array}$ & $\begin{array}{c}\text { Bulb dry weight } \\
\left(\text { g pot }^{-1}\right)\end{array}$ & $\begin{array}{l}\text { Bulb circumference } \\
(\mathbf{c m})\end{array}$ \\
\hline \begin{tabular}{|l|} 
Control \\
\end{tabular} & $37.0 \mathrm{e}$ & $8.3 \mathrm{e}$ & $19.5 \mathrm{e}$ & $6.2 \mathrm{e}$ & $12.3 \mathrm{e}$ \\
\hline Mycorrhizae & $50.2 \mathrm{~d}$ & $10.9 \mathrm{~d}$ & $24.7 \mathrm{~cd}$ & $7.6 \mathrm{~d}$ & $13.9 \mathrm{~cd}$ \\
\hline Bacteria & $46.3 \mathrm{~d}$ & $9.9 \mathrm{de}$ & $23.1 \mathrm{~d}$ & $7.3 \mathrm{de}$ & $13.4 \mathrm{~d}$ \\
\hline$M+B$ & $80.9 \mathrm{a}$ & $18.2 \mathrm{a}$ & $33.1 \mathrm{a}$ & $12.2 \mathrm{a}$ & $15.9 \mathrm{a}$ \\
\hline $\mathrm{M}+\mathrm{O} . \mathrm{M}$ & $64.1 \mathrm{~b}$ & $15.8 \mathrm{~b}$ & $27.3 \mathrm{~b}$ & $9.5 \mathrm{~b}$ & $14.9 \mathrm{ab}$ \\
\hline $\mathrm{B}+\mathrm{O} . \mathrm{M}$ & $61.2 \mathrm{bc}$ & $15.3 \mathrm{~b}$ & $26.9 \mathrm{~b}$ & $9.0 \mathrm{bc}$ & $14.8 \mathrm{bc}$ \\
\hline $\begin{array}{l}\mathrm{M}+\mathrm{B}+\mathrm{O} . \mathrm{M} \\
\text { (no fertilizer) }\end{array}$ & $54.9 \mathrm{~cd}$ & $12.7 \mathrm{c}$ & $25.6 \mathrm{bc}$ & $7.7 \mathrm{~cd}$ & $14.3 \mathrm{~b}-\mathrm{d}$ \\
\hline
\end{tabular}

Mean sharing the same letter(s) do not differ significantly at $\mathrm{P} \leq 0.05$

Table-3: Impact of endomycorrhizae and PGPR along with compost on physiological and chemical parameters of onion.

\begin{tabular}{|l|c|c|c|c|c|}
\hline \multicolumn{1}{|c|}{ Treatments } & $\begin{array}{c}\text { Chlorophyll a } \\
(\mathbf{m g} / \mathbf{L})\end{array}$ & $\begin{array}{c}\text { Chlorophyll b } \\
(\mathbf{m g} / \mathbf{L})\end{array}$ & $\begin{array}{c}\text { Carotenoid } \\
(\mathbf{m g} / \mathbf{L})\end{array}$ & $\begin{array}{c}\text { SPAD } \\
\text { value }\end{array}$ & $\begin{array}{c}\text { Plant phosphorus } \\
\text { uptake }(\mathbf{m g} / \mathbf{L})\end{array}$ \\
\hline Control & $24.1 \mathrm{f}$ & $18.8 \mathrm{e}$ & $1.57 \mathrm{~d}$ & $48.4 \mathrm{e}$ & $1.66 \mathrm{~d}$ \\
\hline Mycorrhizae & $29.8 \mathrm{de}$ & $22.2 \mathrm{c}-\mathrm{e}$ & $2.01 \mathrm{~cd}$ & $60.3 \mathrm{~d}$ & $2.00 \mathrm{~b}-\mathrm{d}$ \\
\hline Bacteria & $27.5 \mathrm{e}$ & $20.79 \mathrm{de}$ & $1.88 \mathrm{~cd}$ & $58.2 \mathrm{~cd}$ & $1.88 \mathrm{~cd}$ \\
\hline M + B & $38.9 \mathrm{a}$ & $32.0 \mathrm{a}$ & $3.09 \mathrm{a}$ & $75.5 \mathrm{a}$ & $2.94 \mathrm{a}$ \\
\hline M + O.M & $35.3 \mathrm{~b}$ & $27.3 \mathrm{~b}$ & $2.57 \mathrm{~b}$ & $70.6 \mathrm{ab}$ & $2.66 \mathrm{ab}$ \\
\hline B + O.M & $33.8 \mathrm{bc}$ & $25.3 \mathrm{bc}$ & $2.35 \mathrm{~b}$ & $69.0 \mathrm{a}-\mathrm{c}$ & $2.41 \mathrm{a}-\mathrm{c}$ \\
\hline M + B + O.M (no fertilizer) & $31.2 \mathrm{~cd}$ & $23.9 \mathrm{~b}-\mathrm{d}$ & $2.09 \mathrm{bc}$ & $64.4 \mathrm{~b}-\mathrm{d}$ & $2.18 \mathrm{~b}-\mathrm{d}$ \\
\hline
\end{tabular}

Mean sharing the same letter(s) do not differ significantly at $\mathrm{P} \leq 0.05$

$\mathrm{M}=$ Mycorrhizae

$\mathrm{B}=$ Bactria

O.M = Organic matter

\section{Physiological parameters}

In present experiment, inoculation of PGPR, G. intraradices and compost significantly enhanced all the physiological parameters. Improvement in chlorophyll "a" and chlorophyll "b" were recorded when treated with endomycorrhizae and PGPR with recommended dose of fertilizer i.e. upto $30 \%, 41 \%$ and $43 \%, 53 \%$ as compared to the application of AMF or rhizobacteria alone, respectively. Similar results were observed in case of SPAD value when inoculated with PGPR and endomycorrhizae together i.e. $25 \%$ and $29 \%$. Percent increase in plant carotenoid contents by $53 \%$ and $64 \%$ was observed when treated with $\mathrm{G}$. intraradices and PGPR together in contrast to application of AMF or PGPR solely. Similarly, combined application of arbuscular mycorrhizae along with rhizobacteria increased chlorophyll "a" by $10 \%$ and $15 \%$, chlorophyll "b" by $17 \%$ and $26 \%$, SPAD value by $6 \%$ and $9 \%$ and carotenoids by $20 \%$ and $31 \%$ as compared to sole application of endomycorrhizae or PGPR, respectively.

\section{Chemical parameters}

In present trial, all the treatments showed significant $(\mathrm{P} \leq 0.05)$ increase in $\mathrm{P}$ uptake as compared to the control. But maximum uptake was observed when plants were treated with endomycorrhizae and rhizobacteria together with recommended dose of fertilizer which was $46 \%$ and $56 \%$ in contrast to alone inoculation of AMF or PGPR, respectively. The treatment in which endomycorrhizae and rhizobacteria were applied together, showed $10 \%$ and $21 \%$ more $\mathrm{P}$ uptake as compared to the treatment in which endomycorrhizae + compost or rhizobacteria + compost were used.

\section{Discussion}

Production of every crop is highly depends upon phosphate fertilizers. However, only $20 \%$ of applied P is utilized by plants (Cordell and White, 2015). So, the application of biological mean like endomycorrhizae or rhizobacteria is one of the appropriate methods to 
enhance P availability (Kunwar et al., 2018). It is due to different mechanisms like phosphorus solubilization, greater soil volume exploration and rapid phosphorus movement into hyphae of mycorrhizae (Bolan, 1991). Similarly, PGPR enhance phosphorus uptake by releasing several organic acids e.g. fumeric acids, butyric acids, citric acids etc. These acids liberate P from its compounds (Kapoor, 1995). Even compost itself is a source of $\mathrm{P}$ and also improves microbial activity in order to enhance $\mathrm{P}$ availability (Khan and Joergensen, 2009). Similarly, in present research, plants treated with G. intraradices and PGPR along with compost showed improvement in plant growth parameters. Combined application of endomycorrhizae and rhizobacteria enhanced the growth of plants which might be due to the enhanced uptake of water and nutrients by AMF due to development of hyphae (Chen et al., 2016). It could be also due to the ability of PGPR to produce phytoharmones which ultimately increase nutrient uptake and thus improve photosynthetic rate and crop yield (Gholami et al., 2009). The inoculation of arbuscular mycorrhizae fungi enhanced the growth parameters (shoot fresh and dry weight, root fresh and dry weight) of leek (Kahiluoto and Vestberg, 1998), while PGPR inoculated bitter guord plants showed better yield, increased growth of root length, dry root mass and quality (Kumar et al., 2012).

Moreover, it was observed by Mehrvarz et al. (2008) that alone application of PSB enhanced biological yield but inoculation of same bacteria with AMF gave maximum grain mass of barley. In present pot trial, application of PGPR and G. intraradices improved the physiological parameters of plant. This might be due to the more harvesting of light during symbiotic relationship, which ultimately enhanced the efficiency of photosynthesis (Wu et al., 2010), due to the enhanced uptake of $\mathrm{P}$ and magnesium by mycorrhizae inoculated plants (Zhu et al. 2014). Also this might be due to the nitrogen fixation ability of rhizobacteria, which enhanced the chlorophyll contents in soybean plants (Wu et al., 2006). Different bacterial strains like Azobacter, Pseudomonas and Azospirillum enhanced the chlorophyll a, chlorophyll $\mathrm{b}$ and total chlorophyll in plants (Al-Erwy et al., 2016).

In present study, Glomus intraradices and PGPR inoculated plants showed maximum uptake of $P$. This might be due to the development of fungal hyphae which helped in the uptake of P (Gong et al., 2013). Moreover, this can be also due to the ability of PGPR to mobilize the insoluble $\mathrm{P}$ by synthesizing organic acids, chelating substances, growth hormones and enhanced nitrogen fixation rate (Khan et al., 2007). The inoculation of Pseudomonas and AMF together enhanced the total concentration of $\mathrm{P}$ in plants (Akhtar and Siddiqui, 2008).

In present research, application of PGPR with compost or G. intraradices with compost also enhanced all parameters as well as P uptake as compared to control. These results are in accordance to Perner et al. (2006), who found that application of AMF with compost enhanced the growth, potassium and $\mathrm{P}$ uptake. This can be due the uptake of macro and micro nutrients which reduced $50 \%$ of availability on chemical fertilizers (Yildirim et al., 2011).

\section{Conclusion}

The use of PGPR, endomycorrhizae and compost can be used to enhance $P$ availability in onion. It was concluded in the light of present study that the use of PGPR, AMF along with compost enhanced the growth and $\mathrm{P}$ uptake in onion as compared to control. The use of PGPR along with AMF maximum enhanced the growth as well as $\mathrm{P}$ uptake by onion. So, by using this method our dependency on chemical fertilizer can be reduced in future.

\section{Disclaimer: None. \\ Conflict of Interest: None. Source of Funding: None.}

\section{References}

Ahemad M and Kibret M, 2014. Mechanisms and applications of plant growth promoting rhizobacteria: current perspective. J. King Saud Uni. Sci. 26(1): 1-20.

Akhtar MS and Siddiqui ZA, 2008. Glomus intraradices, Pseudomonas alcaligenes, and Bacillus pumilus: effective agents for the control of root-rot disease complex of chickpea (Cicer arietinum L.). J. Gen. Plant Pathol. 74(1): 53-60.

Alam SM, Latif A and Iqbal Z, 1994. Phosphorus-zinc interaction in wheat and maize crops, pp. 239-243. In proceedings, $4^{\text {th }}$ National Congress of Soil Science, Islamabad, Pakistan.

Al-Erwy AS, Al-Toukhy A and Bafeel SO, 2016. Effect of chemical, organic and bio fertilizers on photosynthetic pigments, carbohydrates and minerals of Wheat (Triticum aestivum L.) 
Irrigated with Sea Water. Int. J. Adv. Res. Biol. Sci. 3(2): 296-310.

Arnon DI, 1949. Copper enzymes in isolated chloroplasts. Polyphenoloxidase in Beta vulgaris. Plant Physiol. 24: 1.

Baker A, Ceasar SA, Palmer AJ, Paterson JB, Qi W, Muench SP and Baldwin SA, 2015. Replace, reuse, recycle: improving the sustainable use of phosphorus by plants. J. Exp. Bot. 66(12): 35233540.

Balestrini R, Lumini E and Borriello R, 2015. Plantsoil biota interactions, pp. 311-338. In E. A. Paul (eds.), Soil Microbiology, Ecology and Biochemistry. Elsevier, Amsterdam, The Netherlands.

Bolan NS, 1991. A critical review on the role of mycorrhizal fungi in the uptake of phosphorus by plants. Plant Soil. 134(2): 189-207.

Carstensen A, Herdean A, Schmidt SB, Sharma A, Spetea C, Pribil M and Husted S, 2018. The impacts of phosphorus deficiency on the photosynthetic electron transport chain. Plant Physiol.177: 271-284.

Chen W, Koide RT, Adams TS, DeForest JL, Cheng L and Eissenstat DM, 2016. Root morphology and mycorrhizal symbioses together shape nutrient foraging strategies of temperate trees. Proc. Natl. Acad. Sci. 113(31): 8741-8746.

Cordell D and White S, 2015. Tracking phosphorus security: indicators of phosphorus vulnerability in the global food system. Food Sec. 7(2): 337-350.

Elbon A and Whalen JK, 2015. Phosphorus supply to vegetable crops from arbuscular mycorrhizal fungi: a review. Bio. Agric. Hortic. 31(2): 73-90.

Gholami, A, Shahsavani S and Nezarat S, 2009. The effect of plant growth promoting rhizobacteria (PGPR) on germination, seedling growth and yield of maize. Int. J. Biol. Life Sci. 1(1): 35-40.

Glick BR, 2005. Modulation of plant ethylene levels by the bacterial enzyme ACC deaminase. FEMS Microbiol. Lett. 251(1): 1-7.

Gong M, Tang M, Chen H, Zhang Q and Feng X, 2013. Effects of two Glomus species on the growth and physiological performance of Sophora davidii seedlings under water stress. New Forest. 44(3): 399-408.

Hammond JP and White PJ, 2008. Sucrose transport in the phloem: integrating root responses to phosphorus starvation. J. Exp. Bot. 59(1): 93-109. Jackson ML, 1958. Soil chemical analysis. Prentice Hall, Inc., Englewood Cliffs, New Jersey, USA.
498: 183-204.

Jeffries P, Gianinazzi S, Perotto S, Turnau K and Barea JM, 2003. The contribution of arbuscular mycorrhizal fungi in sustainable maintenance of plant health and soil fertility. Biol. Fert. Soils. 37(1): 1-16.

Kahiluoto H and Vestberg M, 1998. The effect of arbuscular mycorrhiza on biomass production and phosphorus uptake from sparingly soluble sources by leek (Allium porrum L.) in finnish field soils. Biol. Agric. Horti. 16: 65-85.

Kapoor KK, 1995. Phosphate mobilization through soil microorganisms. In: Behl RK, Khurana AL, Dogra R C. Eds. Plant microbe interaction in sustainable agriculture. CCS Haryana Agriculture University, Hisar and MMB, New Delhi, India, pp. 46-61.

Khan KS and Joergensen RG, 2009. Changes in microbial biomass and $\mathrm{P}$ fractions in biogenic household waste compost amended with inorganic $\mathrm{P}$ fertilizers. Bioresour. Technol. 100(1): 303-309.

Khan MS, Zaidi A and Wani PA, 2007. Role of phosphate-solubilizing microorganisms in sustainable agriculture-a review. Agron. Sust. Develop. 27(1): 29-43.

Khokhar KM, 2018. Technical Report-Growing onion in Pakistan. HRI, NARC, Islamabad, Pakistan.

Kirk GJD, 1999. A model of phosphate solubilization by organic anion excretion from plant roots. Euro. J. Soil Sci. 50(3): 369-378.

Koide RT and Kabir Z, 2000. Extraradical hyphae of the mycorrhizal fungus Glomus intraradices can hydrolyse organic phosphate. New Phytol. 148(3): 511-517.

Kumar KN, Sowmyamala BV, Kumar PS, Vasudev PN, Kumar RV and Nagaraj HT, 2012. Effect of plant growth promoting rhizobacteria (PGPR) on growth and yield of bitter gourd. Int. J. App. Technol. 3(1): 1-7.

Kunwar VS, Lamichhane J and Gauchan DP, 2018. Strategies to improve phosphorus availability in a sustainable agricultural system. Int. J. Innov. Sci. Res. Technol. 3(9): 323- 331.

Leytem AB and Mikkelsen RL, 2005. The nature of phosphorus in calcareous soils. Better Crops. 89(2): 11-13.

Marschner H, 1995. Mineral Nutrition of Higher Plants. Academic Press, London, UK.

Mehrvarz S, Chaichi MR and Alikhani HA, 2008. Effects of phosphate solubilizing microorganisms 
and phosphorus chemical fertilizer on yield and yield components of barley (Hordeum vulgare L.). J. Agric. Environ. Sci. 3(6): 822-828.

Montgomery DC, 2013. Design and analysis of experiments, $8^{\text {th }}$ ed. John Wiley and Sons Inc. New York, USA.

Nadeem SM, Khan MY, Waqas MR, Binyamin R, Akhtar S and Zahir ZA, 2017. Arbuscular mycorrhizas: An overview, pp. 1-24. In Q. S. Wu (eds.) Arbuscular Mycorrhizas and Stress Tolerance of Plants. Springer, Singapore.

Niaz A, Ranjh, AM, Rahmatullah AH and Waqas M, 2007. Boron status of soils as affected by different soil characteristics- $\mathrm{pH}, \mathrm{CaCO}$, organic matter and clay contents. Pak. J. Agric. Sci. 44(3): 428435.

Olsen SR, 1954. Estimation of available phosphorus in soils by extraction with sodium bicarbonate. USDA Circular Nr 939, US. Gov. Print. Office, Washington, D.C., USA.

Perner H, Schwarz D and George E, 2006. Effect of mycorrhizal inoculation and compost supply on growth and nutrient uptake of young leek plants grown on peat-based substrates. Hort. Sci. 41(3): 628-632.

Prasad M, 2013. A literature review on the availability of phosphorus from compost in relation to the nitrate regulations SI378 of 2006. Small scale study report prepared for the Environmental Protection Agency by Cre-composting Association of Ireland, STRIVE-program, Republic of Ireland.

Raghothama KG, 1999. Phosphate acquisition. Ann. Rev. Plant Biol. 50(1): 665-693.

Rengel Z and Zhang F, 2011. Phosphorus sustains life. Plant Soil. 349(1-2): 1-2.

Sharma SB, Sayyed RZ, Trivedi MH and Gobi TA, 2013. Phosphate solubilizing microbes: sustainable approach for managing phosphorus deficiency in agricultural soils. Springer Plus. 2(1): 587.

Shen J, Yuan L, Zhang J, Li H, Bai Z, Chen X, Zhang $\mathrm{W}$ and Zhang F, 2011. Phosphorus dynamics: from soil to plant. Plant Physiol. 156: 997-1005.
Tanwar A, Aggarwal A, Karishma and Neetu, 2012. Effectiveness of endomycorrhizal fungi and Pseudomonas fluorescens under different phosphorus levels on Capsicum annuum $\mathrm{L}$. Kasetsart J. Nat. Sci. 46: 769-782.

Tawaraya K, Naito M and Wagatsuma T, 2006. Solubilization of insoluble inorganic phosphate by hyphal exudates of arbuscular mycorrhizal fungi. J. Plant Nutr. 29(4): 657- 665.

Williamson LC, Ribrioux SP, Fitter AH and Leyser HO, 2001. Phosphate availability regulates root system architecture in Arabidopsis. Plant Physiol. 126(2): 875-882.

Wu QS, Zou YN and He XH, 2010. Contributions of arbuscular mycorrhizal fungi to growth, photosynthesis, root morphology and ionic balance of citrus seedlings under salt stress. Acta Physiologiae Plantarum. 32(2): 297-304.

Wu SC, Cheung KC, Luo YM and Wong MH, 2006. Effects of inoculation of plant growth-promoting rhizobacteria on metal uptake by Brassica juncea. Environ. Pollut. 140(1): 124-135.

Yildirim E, Karlidag H, Turan M, Dursun A and Goktepe F, 2011. Growth, nutrient uptake and yield promotion of broccoli by plant growth promoting rhizobacteria with manure. Hort. Sci. 46(6): 932-936.

Zhu XQ, Wang CY, Chen H and Tang M, 2014. Effects of arbuscular mycorrhizal fungi on photosynthesis, carbon content, and calorific value of black locust seedlings. Photosynthetica. 52(2): 247-252

\section{Contribution of Authors}

Shahzad F: Conducted research, collected and analyzed data

Asghar HN: Planned and supervised research

Mushtaq Z: Helped in execution of research

Hadayat A: Collected and analyzed data

Zuhra N: Collected and analyzed data

Ahmad R: Analyzed data

Ali MA: Provided host soil of arbuscular endomycorrhizae fungi and helped in data collection 